ORIGINAL RESEARCH ARTICLE

\title{
THE QUALITY AND TOTAL MICROBES OF BROILER CHICKEN IN TRADITIONAL MARKETS OF DENPASAR CITY
}

\author{
Luh Yuni Surya Antari ${ }^{1 *}$, I N. Tirta Ariana ${ }^{2}$, and G. A. M. Kristina Dewi ${ }^{2}$ \\ ${ }^{1}$ Study Program of Magister Animal Science, Faculty of Animal Science, \\ Udayana University \\ ${ }^{2}$ Faculty of Animal Science, Udayana University \\ *Corresponding author: ysuryaantari@gmail.com
}

Received : $18^{\text {th }}$ November $2016 \mid$ Accepted $: 17^{\text {th }}$ February 2017

\begin{abstract}
The purpose of this study was to determine the quality and total microbes of broiler at different location at the traditional markets in Denpasar City. This study used a completely randomized design (CRD) with four treatments. The treatments used in this study, broiler chicken sold at traditional markets in East (DT), North (DU), West (DB), and South of Denpasar (DS). The data obtained from this study were analyzed with analysis of variance. If there were significant differences $(P<0,05)$ among the treatments, then continued with Duncan's multiple range test. The variables used in this study were carcass weight, cooking loss, drip loss, water holding capacity, water content, protein, fat, ash, and total microbes. The results showed that on the average, the highest carcass weight in DB treatment was 1.482 grams, with other treatments to get results not significantly different $(\mathrm{P}>0,05)$. The result of this study for variable drip loss, water content, protein, fat, and ash significantly different $(\mathrm{P}<0,05)$, then research result for cooking loss, and water holding capacity, were not significantly different $(\mathrm{P}>0,05)$. The research result for total microbies broiler chicken at traditional markets in Denpasar City have a range of $1,84 \times 10^{4}$ to 2,62 x $10^{4} \mathrm{CFU} / \mathrm{gram}$. The results were still normal when compared to SNI 7388: 2009 which states that the maximum amount that the content of TPC $1 \times 10^{6} \mathrm{CFU} / \mathrm{gram}$. From these results, it was concluded that there were similarities quality of broiler chicken (carcass weight, cooking loss, water holding capacity, and total microbes), however, there were differences in the quality of broiler seen from drip loss, water content, protein, fat, and ash of broiler at traditional markets in Denpasar City.
\end{abstract}

Keywords: Broiler, Traditional Market, Quality of Meat, Microbies of Meat

\section{INTRODUCTION}

Broiler is one of the livestock problems of chicken is the rampant sale products that play a role in fulfilling the of chicken originating from chicken that needs of animal protein, where in 2014, expired or die before cutting, chicken the average consumption of chicken per that comes from slaughtering process capita in a week is $0.086 \mathrm{~kg}$. (Badan that is not good (Ibrahim, 2004). Pusat Statistik, 2015). One of the Traditional market is one marketing 
place of daily needs which one of them is broiler chicken.

In Denpasar City, the improvement of traditional market conditions by the City government is committed to empower the traditional markets as an effort to develop the people's economy. The revitalization of traditional markets has a positive impact on traders and communities. The number of traders in the markets in Denpasar City, based on data Central Bureau of Statistics Denpasar 2014, as many as 7,542 people, or increased 67 people since 2013 (Yudistira, 2015). Based on this matter, the research was conducted on physical and chemical quality of broiler chicken in traditional market of Denpasar City.

\section{MATERIALS AND METHODS}

Sample on this research is taken at four traditional markets in Denpasar (traditional market of East (DT), North (DU), West (DB), and South of Denpasar (DS)). Chicken sample used the breast chicken for chicken quality. The research was conducted at the Laboratory of Animal Product Technology and Microbiology, Faculty of Animal Science and Laboratory of Faculty of Agricultural Technology, Udayana University, Denpasar-Bali. The study lasted eight weeks, beginning in early November 2016 until the end of December 2016. This research used a completely randomized design (CRD) with four treatments. The variables that are measured in the research were: carcass weight, cooking loss, drip loss, water holding capacity, water content, protein, fat, ash, and total microbes. The data obtained from this research are analyzed by analysis of variance, then continued by Duncan's multiple-range test (Steel and Torrie, 1989). The data processing was done by the SPSS 16 program.

\section{RESULTS AND DISCUSSION}

\section{Carcass Weight}

Carcass weight of the broiler chickens that circulated in the traditional market of Denpasar City was $1.481 \mathrm{~g}$. The results showed that carcass weight of the broiler chickens was carcass weight that many consumers demand. According to Dewi et al. (2014) the increasing of the digestible feed in the chicken resulted in much nutrients being absorbed and molded into meat and reflected in carcass weight as high as percentage of carcass. In addition, increasing the carcass weight and carcass percentage is closely related to weight of pieces (Antari et al., 2015). 


\section{Cooking Loss}

The average of broiler chicken's cooking loss of DT was $31.38 \%$ and it was not statistically significant $(\mathrm{P}>0.05)$ with the average of broiler chicken's cooking loss of DB, DU, and DS. The broiler chicken with the lower cooking loss has a better relative quality than broiler chicken with the greater cooking loss, because, the loss of nutrients during cooking will be slight (Soeparno, 2009). This is in accordance with Prayitno et al. (2010) the smaller percentage of cooking loss means the less of lossed water and nutrients that dissolve in the water.

Table 1.The Quality and Total Microbes of Broiler Chicken in Traditional Markets of Denpasar City

\begin{tabular}{|c|c|c|c|c|c|c|}
\hline \multirow[t]{2}{*}{ Variables } & \multicolumn{4}{|c|}{ Treatments $^{1)}$} & \multirow[t]{2}{*}{ Standard } & \multirow[t]{2}{*}{$\mathrm{SEM}^{2)}$} \\
\hline & DT & $\mathrm{DB}$ & DU & DS & & \\
\hline Carcass Weight (g) & $1.481,0^{\text {a } 3)}$ & $1.481,6^{\mathrm{a}}$ & $1.480,2^{\mathrm{a}}$ & $1.479,2^{\mathrm{a}}$ & & 4,23 \\
\hline Cooking Loss (\%) & $31,38^{\mathrm{a} 3)}$ & $32,68^{\mathrm{a}}$ & $32,80^{\mathrm{a}}$ & $32,82^{\mathrm{a}}$ & $28,1-34,48^{4)}$ & 0,31 \\
\hline $\begin{array}{l}\text { Water Holding } \\
\text { Capacity }(\%)\end{array}$ & $34,43^{\mathrm{a}}$ & $34,28^{\mathrm{a}}$ & $34,22^{\mathrm{a}}$ & $34,15^{\mathrm{a}}$ & $30,22^{5)}$ & 0,68 \\
\hline Drip Loss (\%) & $10,26^{\mathrm{a}}$ & $11,97^{\mathrm{b}}$ & $12,14^{\mathrm{b}}$ & $12,16^{\mathrm{b}}$ & $4,57-5,10^{6)}$ & 0,26 \\
\hline Water Content (\%) & $73,24^{\mathrm{b}}$ & $65,49^{\mathrm{a}}$ & $63,54^{\mathrm{a}}$ & $63,33^{\mathrm{a}}$ & $65-80^{8)}$ & 0,42 \\
\hline Protein $(\%)$ & $25,35^{\mathrm{b}}$ & $24,49^{\mathrm{ab}}$ & $24,03^{\mathrm{a}}$ & $23,96^{\mathrm{a}}$ & $16-22^{8)}$ & 0,17 \\
\hline Fat $(\%)$ & $5,09^{\mathrm{a}}$ & $5,81^{\mathrm{a}}$ & $9,60^{\mathrm{b}}$ & $9,74^{\mathrm{b}}$ & $1,5-13^{8)}$ & 0,20 \\
\hline Ash (\%) & $1,24^{\mathrm{b}}$ & $1,20^{\mathrm{ab}}$ & $1,19^{\mathrm{ab}}$ & $1,09^{\mathrm{a}}$ & $1^{9)}$ & 0,02 \\
\hline $\begin{array}{l}\text { Total Microbes } \\
\text { (CFU/gram) }\end{array}$ & $2,45 \times 10^{4 a}$ & $1,84 \times 10^{4 a}$ & $2,62 \times 10^{4 a}$ & $2,22 \times 10^{4} \mathrm{a}$ & $1 \times 10^{610)}$ & 0,13 \\
\hline
\end{tabular}

Information :

1) DT: Broiler ChickenSold at Traditional Market in Denpasar East, DB: Broiler ChickenSoldat Traditional Market in West Denpasar, DU: Broiler ChickenSold atTraditional Market in North Denpasar, DS: Broiler Chicken Sold at Traditional Market in South Denpasar.

2) SEM (Standard Error of Means)

3) The values with the same superscript on the same line show no significant difference (P> $0.05)$

4) Source: Kasih et al. (2012); 5) Source: Fernando (2007); 6) Source: Fauziah (2014); 7) Source: Suradi (2008); 8) Source: Soeparno (2011); 9) Source: Campbell and Lasley (1975) in Anggorodi (1985); 10) Source: SNI 7388: 2009

\section{Water Holding Capacity}

The average of broiler chicken's water holding capacity of DT was of DB, DU, and DS. The higher the $34,43 \%$ and that was not statistically protein content of broiler chicken, the significant $(\mathrm{P}>0,05)$ with the average of broiler chicken's water holding capacity 
higher the water holding capacity, formation of protein and fat was not because of the protein's ability inholding completely perfect (Rosyidi et al., 2010). water chemically and increasingly according to the fat content (Oktaviana, 2009).

\section{Protein Content}

Statistically, the broiler chicken's

\section{Drip Loss}

The average of broiler chicken's drip loss of DT was $10.26 \%$ and it was statistically significantly different $(\mathrm{P}$ $<0.05)$ with the average of broiler chicken's drip loss of DB, DU, and DS (Table 1). Drip loss was related to the water holding capacity of the chicken. When the water holding capacity increases, then the drip will decrease (Soeparno, 2009). Furthermore, Sriyani et al. (2015) suggested that the differences of family in livestock have a significant effect on the value of drip loss which was produced, where the drip loss was in line with the value of cooking loss.

\section{Water content}

The average of broiler chicken's water content of DT was $73,67 \%$ and it was statistically significantly different ( $P$ $<0,05)$ with the average of broiler chicken's water content of DB, DU, and DS. High water content was due to the young age of the livestock, since the

\section{Fat Content}

The average of broiler chicken's fat content of DT is $5.09 \%$ was statistically significantly different (P $<0.05)$ with the average of broiler chicken's fat content of DU, and DS and was not significantly different $(\mathrm{P}>0,05)$ with the broiler chicken's fat content of DB. The high fat content in broiler chicken of DU and DS can be caused on feed content which was consumed by 
broiler chicken when it kept. As what Ariana and Suranjaya (2016) stated that high carcass fat was the result of highenergy rations.

\section{Ash Content}

The results showed that the average of broiler chicken's ash content of DT was $1.24 \%$ and it was statistically significantly different $(\mathrm{P}<0.05)$ with the average of broiler chicken's ash content of DB, DU, and DS (Table 1). The ash content showed total minerals in a food. Organic materials in the combustion process will burn but not as in the inorganic components that so-called ash content (Astuti, 2011).

\section{Total Microbes}

Total microbes results showed that total of broiler chicken's microbes that circulated in traditional market of Denpasar City was not significant (P) $0,05)$. The average of broiler chicken's total microbes of DT was $2.45 \times 104$ CFU / gram. Microbial contamination of broiler chicken proceeds from the infected chicken or post-mortem contamination (Ariana et al., 2014). According to SNI 7388: 2009 described the maximum amount of TPC content was 1x106 CFU / gram. Broiler chicken which was sold in the traditional market of Denpasar City was still in accordance with the standard since it has number of total microbes below the maximum limit of the standard. The low TPC on all the broiler chicken sold by the traders in the market was likely to be still fresh (freshly slaughtered of broiler chicken) as well as the time between the slaughtering to purchases of less than 4 hours, so minimizing the contamination at the time of sale resulting in fewer bacterial growth.

\section{REFERENCES}

Anggorodi, R. (1985). Kemajuan Mutakhir Ilmu Makanan Ternak Unggas. First Published. Indonesia University Press. Jakarta.

Antari, L. Y. S., Ariana, I. N. T., \& Siti, N. W. (2015). Pengaruh penambahan probiotik starbio dalam ransum komersial terhadap produksi ayam broiler. Journal of Tropical Animal Science, 3 No. 2 Th. 2015: $259-270$.

Ariana, I. N. T., \& Suranjaya, I. G. (2016). Kualitas kimia daging sapi bali yang diberi pakan sampah kota. Udayana Serving Journal, 15 No 3 Th 2016.

Ariana, I. N. T., Sriyani, N. L. P., Oka, A. A., Suranjaya, I. G., \& Dewantari, M. (2014). The effect of starbio on broiler meat mikrobial's profil and the environmental impact of sustainable farm. (online series), [accessed onApril 10 2017]. Accessedfrom :URL http://erepo.unud.ac.id/4466/

Astuti. (2011). Kadar Abu. (online series), [accessedon February 10 2017]. Accessed from :URL :http://astutipage.wordpress.com/ta g/kadar-abu/. 
Badan Pusat Statistik. (2015). Konsumsi Rata-Rata per Kapita Seminggu Beberapa Macam Bahan Makanan Penting. (online series), [accessedon September 25 2016]. Accessed from : URL : https://www.bps.go.id/linkTabelSt atis/view/id/950

Dewi, G. A. M. K., Wijana, I. W., Siti, N. W., \& Mudita, I. M. (2014). Pengaruh penggunaan limbah dan gulama tanaman pangan melalui produksi biosuplemen berprobiotik berbasis limbah isi rumen terhadap ternak itik bali. (online series), [accessed on May 10 2017]. Accessed from :URL:http://lppm.unmas.ac.id/wpcontent/uploads/2014/06/75KRIST INA-DEWI_MUDITA.pdf

Fauziah, R. R. (2014). Peningkatan Keempukan Daging Ayam Petelur Afkir Dengan Metode Injeksi Antemortem Ekstrak Kasar Enzim Protease dari Tanaman Biduri dan Pepaya. Research of Initiator Lecturers. Jember University. Jember.

Fernandez, C., Sanchez-Seiquer, P. \& Sanchez, A. 2003. Use of total mixed ration with three sources of protein as an alternative feeding for dairy goats on Southeast of Spain. Pakistan J. Nut. 2: $18-24$

Fernando, D. (2007). Sifat Fisik dan Organoleptik Daging Ayam Broiler yang Diberi Pakan dengan Penambahan Tepung Daun Sambiloto. Undergraduate Thesis. Bogor Agricultural Institute. Bogor.

Ibrahim, M.A. (2004). Makanan dan Minuman Halal. Bogor Agricultural Institute. Bogor.

Kasih, N. S., Jaelani, A., \& Firahmi, N. (2012). Pengaruh lama penyimpanan daging ayam segar dalam refrigerator terhadap $\mathrm{pH}$, susut masak dan organoleptik. J. Med Sains. 4 (2):154-159
Oktaviana, D. (2009). Pengaruh pemberian ampas virgin coconut oil dalam ransum terhadap performan, produksi karkas, perlemakan, antibodi, dan mikroskopik otot serta organ pencernaan ayam broiler. Thesis. Faculty of Animal Science Gadjah Mada University. Yogyakarta.

Prayitno, A. H., Suryanto, E. \& Zuprizal. (2010). Kualitas fisik dan sensoris daging ayam broiler yang diberi pakan dengan penambahan ampas virgin coconut oil (VCO). Buletin Peternakan. 34 (1):55-63

Rosyidi, D., Susilo, A., \& Wiretno, I. (2010). Pengaruh bangsa sapi terhadap kualitas fisik dan kimiawi daging. Jurnal Ilmu dan Teknologi Hasil Ternak. Brawijaya University. Malang. Vol. 5 No. 1, hal 11-17

Soeparno. (2009). Ilmu \& Teknologi Daging. Gadjah Mada University Press. Yogyakarta.

Soeparno. (2011). Ilmu \& Gizi Daging. Gadjah Mada University Press. Yogyakarta.

Sriyani, N. L. P., Artiningsih Rasna, N. M., Lindawati, S. A., \& Oka, A. A. (2015). Studi perbandingan kualitas fisik daging babi bali dengan babi landrace persilangan yang dipotong di rumah potong hewan tradisional. Anima Science Magazine. Vol18 No 1.

Standar Nasional Indonesia. (2009). Batas Maksimum Cemaran Mikroba dalam Pangan. Badan Standarisasi Nasional. Jakarta.

Stell, R. G. D., \& Torrie, J. H. (1989). Principles and Procedures of Statistics. ${ }^{\text {nd }}$ Edition. Megraw-Hill International Book Compani. London.

Suradi, K. (2008). Perubahan Sifat Fisik Daging Ayam Broiler Postmortem Selama Penyimpanan Temperatur Ruang. Tesis. Faculty of Animal 
Science, Padjadjaran University.

Bandung.

Yudistira, C. (2015). Kota Denpasar:

Berdayakan Pasar Tradisional.

(online series), [Accessed on

August 10 2016]. Accessed from :

URL : http://regional.kompas.com 